\title{
Investors' Purchasing Behaviour via a Behavioural Finance Approach
}

\author{
Dr. Duygu Firat \& Dr. Sibel Fettahoglu \\ Business Administration Department \\ Faculty of Economics and Business Administration Sciences, Kocaeli University \\ 41380 Umuttepe, Kocaeli, Turkey \\ E-mail: dfirat@kocaeli.edu.tr; stopdemir@kocaeli.edu.tr
}

Received: January 4, 2011 Accepted: February 10, 2011 doi:10.5539/ijbm.v6n7p153

The authors are grateful to Kocaeli University's Scientific Research Projects Unit for their encouragements.

\begin{abstract}
According to the Efficient Markets Hypothesis, investors have complete knowledge regarding the financial markets. As a result, they behave rationally. However, investors are affected by internal and external factors when making decisions. Therefore, the objective of the study examines investors' profiles and to distinguish different demographic groups in terms of their perspective towards stock markets, other financial markets and socio - cultural factors. The other objective of the study is to gauge the importance scale of the factors that drive investors purchase behaviour in the decision-making process. The questions of which social dynamics determine prices in markets which factors investors take into account and which information resources they use when making decisions have not been adequately investigated in the Turkish context, Kocaeli, an industrial city, was preferred as a sampling area. ANOVA and $\mathrm{X}^{2}$ were used to test variables. As a conclusion, investors are not always rationally, they behave with their feelings in decision making process of investment.
\end{abstract}

Keywords: Purchasing behaviour, Behavioural finance, Decision-making, Efficient markets hypothesis, Kocaeli

\section{Introduction}

Strategic management and finance concern investors' performance in competitive markets. The study of finance is generally based on the Efficient Markets Hypothesis (EMH). Strategic management gives more importance to observed behaviours related to inefficient markets. According to EMH, the market includes rational investors, who value securities based on the net present value of future earnings' flows discounted by the investments' risk characteristics. Here, rationality refers to choosing an alternative from all alternatives that maximises expected value or utility. However, EMH assumes that markets are in equilibrium in other words investors could not behave individually to increase their expected returns above their expected market return (Bromiley and Wade, 2003).

Behavioural finance does not aim to define rational behaviour or the decision making process as being biased or faulty. Behavioural finance is aimed to predict and understand the systematic financial market implications of psychological decision processes. Additionally, behavioural finance focuses on the implementation of psychological and economic principles to improve financial decision-making processes. Finance, economics and psychology accept the existence of mental decision-making models, but finance and economics differ from psychology in that they are primarily concerned with prediction; consequently, financial and economic theorists can freely construct abstractions of the decision-making process. The Capital Asset Pricing Model (CAPM), arbitrage pricing theory and option pricing models are analytical and normative approaches. It was assumed by finance that investors are rational and that they want to maximise the value of assets (Olsen, 1998).

In recent decades, globalisation in financial markets, competition between businesses, financial institutions and organisations in growing economic, social and economic changes have created uncertainty and instability to the business world. In this respect, financial decision-making processes are becoming more complex and involved. This is due to the complexity in volume and the diversification of new products and services. These new conditions have led to financial researchers addressing financial problems with mathematical techniques. Consequently, financial theory and mathematical models have come together (Zopounidis and Doumpos, 2002).

In the traditional finance literature, an anomaly is defined as market movement that is not consistent with EMH. Many cases in financial markets are not explainable by EMH (Bostanci, 2003). In EMH, prices do not reflect instantly the new knowledge that investors gain. Investors sometimes under-react to new knowledge or overreact to the same knowledge. Volatility is insignificant according to EMH. 
In $\mathrm{EMH}$, investors have complete knowledge regarding the financial markets. As a result, investors behave rationally. However, investors are affected by internal and external factors when they make decisions. Decision making process can be seen in Figure 1 (Assael, 1984).

\section{Figure 1 here}

According to Daniel, Hirshleifer and Subrahmanyam (1998), investors give more importance to knowledge that is acquired by themselves. Investors give importance to whispers.

Behaviours are affected by society' value judgments, symbols and thought patterns. Macgregor (2002) has indicated that investors' positive impressions of a business are affected by stock price forecasts.

Previous research scantly focuses on which social dynamics determine prices in markets which factors in the decision-making process and which information investors use when making decisions in Turkey (Bostanci, 2003). Therefore, the objective of the study is to learn investors' profile and to distinguish different demographic groups in terms of investors' perspective towards the bourse, financial markets and socio-cultural factors. The other objective of the study is to learn the important factors that derive investors' purchase behaviour in the decision-making process.

\section{Basics of Behavioural Finance}

Behavioural finance has many definitions:

Behavioural finance is the integration of economic and finance with psychology and the decision - making sciences. Behavioural finance is an attempt to explain what causes some of the anomalies that have been observed and reported in the finance literature (Fuller, 1998). Behavioural finance relates how stock prices are affected by investors' behaviours (Barak and Demireli, 2006). Behavioural finance consists of two basic constructs: Cognitive psychology and the limits to arbitrage. The term 'cognitive' relate to how people think. Investors' preferences may also create distortions. Behavioural finance uses models that are irrational, either because of preferences or because of mistaken believes. Modern finance is based on EMH. An assumption of EMH is that competition between investors drives prices to their appropriate value. EMH does not assume that all investors are rational, but it does assume that markets are rational. EMH does not rely on the assumption that markets can provide the future, but it does rely on the assumption that markets are objective to predict the future. In contrast, behavioural finance relies on the assumption that, in some circumstances, financial markets are inefficient. If it is easy to take positions and these misevaluations are certainly correctable over a short period, arbitrageurs will take positions and eliminate mispricings, eventually leading to equilibrium (Ritter, 2003).

Anomaly defines as investors behave irrationality because of some factors according to EMH. In this respect, in the traditional finance literature, an anomaly is defined as a market movement that is not consistent with EMH (Bostanci, 2003).

In the international literature, anomalies have two types: Seasonal anomalies and price anomalies. Seasonal anomalies are anomalies that occur before or after hourly, daily, weekly, monthly or yearly periods or over any regular period. Price anomalies indicate deviations from market efficiency, which result after overreaction, under-reaction or insufficient reaction.

Recent empirical research in finance has identified two regularities: Under-reaction and overreaction. The evidence for under-reaction shows that over horizons of one to twelve months, security prices under-react to news such as announcements about dividends. As a result, news incorporated slowly into prices, which tend to exhibit positive autocorrelations over these horizons. The overreaction evidence shows that, over longer horizons of three to five years, security prices overreact to consistent patterns of news pointing in the same direction. Securities that have had a long record of good news tend to become overpriced and have low average returns afterwards (Barberis, Shleifer and Vishny, 1998).

The evidence presents a challenge to EMH because it suggests that, in a variety of markets, sophisticated investors can earn supreme returns by taking advantage of under-reaction and overreaction without taking on extra risk. (Barberis, Shleifer and Vishny, 1998). Another reason that leads to a decrease of belief in EMH is that investors and researchers react linearly to new data. For example, in some cases, investors overreact when selling loosing stocks or buying winning stocks, but in some cases, investors under-react. Overreaction or under-reaction deviates stock prices from rational market values (Dom, 2003).

In behavioural finance, investors are normal rather than rational. Behavioural finance is bases on the assumption that most investors make choices based on limited information As a result, investors' choices typically are not the ones that would maximise the utility of rational investors; rather investors' choices satisfy investors whose rationality is bounded by the limited availability of information and limited cognitive ability. Representing an example are green funds, which invest only in companies that are friendly to the environment or socially responsible funds that avoid investing in companies whose main business is to produce and sell "sin products" such as cigarettes and alcohol. Under behavioural finance, investors do not consider only risk and return when making investment decisions but rather consider many other variables (Estrada, 2001). The assumptions of behavioural finance and EMH can be seen in Table 1. 


\section{Table 1 here}

\section{Methodology}

\subsection{Sampling}

The survey was administered to 504 investors who lived in Kocaeli and made investments. The selection was made by random sampling.

\subsection{Variables of Study}

To learn investors' profile, demographic variables such as gender, education, age, marital status, job, the number of bargain and the amount of investment in the stock market and the importance rate of variables that affect investors' decision-making process were used. Closed - ended questions were used for these variables.

Regarding the markets, accepted ideas in financial markets by investors, socio - cultural factors were assigned by investigating other studies. A five - point Likert scale was used to measure these variables.

\subsection{An Overview of Past Studies}

Some investors try to spot trends and turning points in stock prices. Investors are optimistic in bull markets and pessimistic in bear markets. The effect of diversification is important in modern portfolio theory. However, it believed that risk can still manage with knowledge and trading skill. Encourage investors to plays wealth in few assets. Investors often imagine that their equity exposure is limited because in bear markets, investors in bear market will have the presence of mind to sell quickly. Investors in bear markets thus expect that investors' losses will also be limited (de Bondt, 1998).

Daniel, Hirshleifer and Subrahmanyam have indicated that investors give more importance to self - acquired knowledge. Investors give importance to whispers (Daniel, Hirshleifer and Subrahmanyam, 1998).

Regret had the negative affect experienced after realizing, counterfactually that another choice would have led to a better outcome (Statman, 2002). Regret may drive investors to avoid selling stocks that have gone down because of the chance that the stocks later regain their value. And they may sell stocks that have gone up so they can avoid regretting the failure to do so before the stocks (Shiller, 1998).

A study at Sanliurfa in Turkey indicates that when investors' education level decreases, their tendency to view bourses as a gamble increases (Akbulut and Kaderli, 2009).

In a study, the majority of investors (\% 69) were optimistic. Optimistic investors thought that in the future, they will have higher returns than the market average (Ateş, 2007). A study about the effect of religion on investors' decision-making process indicated that 45 per cent of respondents were affected by religion (Ateş, 2007).

Investors were affected by society when they were making decision. This subject is being evaluated in term of making a purchase in a financial market; studies have shown that investors behave with herd behaviour (Ateş, 2007; Canbas and Kandir, 2007).

\subsection{Analysis}

Frequency tables used to learn the profile of investors. An ANOVA used to distinguish different demographic groups in terms of their perspective regarding bourses, financial markets and socio-cultural factors. $\mathrm{X}^{2}$ (Chi-Square) used to test the relation between preferred profit and the average investment amount in a month.

\subsubsection{Demographic Profile of Respondents}

The survey was distributed to 504 investor's selected using random sampling. Table 2 presents a summary demographic profile of the investors.

\section{Table 2 here}

More than half of the respondents were between 25-44 years old (\% 65). Also, more than half of respondents' education level at the university, graduate and PHD level (\%65). It can thus be interpreted that investors' education level in Kocaeli was above high school.

As appears in Table 2, 60 per cent of respondents were earned more than average 2000 TL in a month. In spite of this, it is apparent that the rate of investors whose income was under 1000 TL was 5 per cent.

Approximately 13 per cent of respondents were female, and 87 per cent of them were male. From this point of view, it can be said for the case of Kocaeli that male investors are more active in the bourse than females.

It appeared that approximately half of respondents' occupations were in the private sector (\% 47). On the other hand, the rate of students and unemployed respondents' was 2 per cent. Consequently, it can be said that income was an important factor of purchasing in the bourse.

When looking at the transaction year in the bourse, nearly half of respondents made transactions for the last five years (\% 45). Regardless, the rate of respondents who made purchases in a bourse for 6-10 years was 27 per cent. The rate of respondents who made purchases in a bourse for more than 10 years was 28 per cent. As a result of this, it can be seen that investors have begun to make transactions in the bourse over the last 5 years.

It is learnt that half of the respondents had made investments of more than 3000 TL (\% 49). 


\subsubsection{Rate of Importance}

Table 3 shows the importance rate of factors that affect investors' decision-making process in the bourse. According to Table 3, political instability is the most important factor for respondents. Otherwise, the importance of the factor is as follows in orderly: Past performance of stocks, improvements in international financial markets and risk level of investment instruments. On the other hand, the directions of intermediations, the inflation ratio and news about stocks in media affected respondents' decision-making less than other factors.

\section{Table 3 here}

\section{"The bourse is a gamble"}

When investors made investments without any knowledge about the investment instruments have not exceeded to forward as playing gamble. It learnt that investors who made investments in the bourse for more than 10 years agreed less than other investors to the opinion "the bourse is a gamble". When it investigated according to education level, agreement with the item "the bourse is a gamble" decreases as the education level increases. Consequently, for Kocaeli, it did not acquire significance result in the way of education (Table 4).

When the item "The bourse is gamble" investigated according to occupation, is showed that people with other occupations (unemployment, student etc.) and the public sector significantly deviated from other occupations (Table 4).

\section{Table 4 here}

\section{"When deposit rates decrease, the bourse is the only investment area."}

Table 5 here

As a result of analysis, it showed that younger respondents were more likely to use the bourse than older respondents. Potentially, this situation explained why younger respondents want to increase the size of their portfolios. In any case, older respondents' chose safer investment areas, such as getting deposit rates (Table 5).

When the item "When deposit rates decrease, the bourse is the only investment area" investigated according to marital status, it found that singles prefer to make investments in the bourse more than married couples do. Couples with a family incentive made safer investments to avoid taking risks (Table 5).

"Over periods of price increases or decreases, the bourse is a convincing investment instrument for investors who want to invest over the long term."

Respondents who made monthly investments above of $3000 \mathrm{TL}$ thought that, during periods of price increases or decreases, the bourse is a convincing investment instrument in the long term (Table 6).

The transaction year in the bourse increases, respondents, who try to make technical analysis for stock prices in markets, choice long term investments. As a result of this, it can be said that investors who make long term investments prefer to wait (Table 6).

\section{Table 6 here}

\section{"I think I have enough knowledge about the bourse."}

Respondents who made investments for more than ten years trusted themselves. As a consequence of this, they thought that they had enough knowledge about the bourse (Table 7).

Table 7 here

"Investors who ensured the viability of an investment portfolio by purchasing stocks on hand are always more profitable than investors who wait for the long term."

As a result of the analysis, young respondents, single respondents and respondents whose stock exchange period was between $0-5$ years prefer to purchase stocks for value increases rather than wait (Table 8).

\section{Table 8 here}

\section{"I think that in the coming year, investments provide higher returns than the average market."}

Singles are more optimistic than married people. Married people, with a family incentive, approach a future more pessimistically (Table 9).

Respondents who make investments over $2001 \mathrm{TL}$ in a month showed more optimism for the future. This optimism leads them to make larger investments (Table 9).

\section{Table 9 here}

\section{"If stocks I purchased lose, I prefer to wait to claim my losses."}

When examining the relationship between income and the item "if stocks I purchased losses I prefer to wait to claim my losses", respondents whose income is up to 2000 TL were reluctant to sell their stocks in periods of price decreases to prevent financial loss (Table10).

Table 10 Here

"My religious beliefs have an important effect on my investment decisions." 
The item "my religious beliefs have an important effect on my investment decisions revealed that the males are more conservative than the females (Table 11).

In terms of education, investors who are at the primary level are thought that religious beliefs. They invest in safer areas such as gold, real estate property and etc. instead of stocks because buying stocks illicit thoughts (Table 11).

\section{Table 11 here}

\section{"Investment instruments that investors choose more always provide higher returns."}

In light of data, females trusted their environments. As a consequence, they behaved with herd psychology (Table 12).

As the transaction year in bourse increases, respondents move away from herd psychology because confidence in themselves as a consequence of the experience that they have (Table 12).

When the question is evaluated in terms of education, respondents behave in herd psychology at a low education level. However, as the level of education increases, they move away from herd psychology (Table 12).

\section{Table 12 here}

\section{Preferred Investment Profit Chosen by Investors}

As Table 13 shows, $\% 56$ of respondents prefer to choose at $\% 100$ probability a profit of 3000 TL despite possibly earning a profit of $4000 \mathrm{TL}$ at an $\% 80$ probability. Therefore, in this way, they choose to take low risk over high profit. From this point of view, respondents tend to choose guaranteed investment options instead of taking risk.

\section{Table 13 here}

When the relationship between preferred profit and average investment amount in one month is examined, investors who made low investments preferred a $3000 \mathrm{TL}$ profit at a $\% 100$ probability instead of the other option. As a consequence, respondents who prefer to invest less do not want to take risks (Table 14).

\section{Table 14 here}

When looking into previous studies some inferences can be concluded in the following:

When examining the relationship between income and the item "if stocks I purchased losses I prefer to wait to claim my losses" is parallel with de Bondt (1998) studies.

Trusting of male investors to themselves is the same sense with Daniel, Hirshleifer and Subrahmanyam (1998) study.

When the relation between education and "bourse is a gamble" is examined, the result of study is parallel with Akbulut and Kaderli (2009)'s study.

In Ates (2007)'s study the percent of 69 investors are optimistic. Despite that, in this study this percentage decreases to 51,2. Herein, it can be said that economic crisis's effect on this result. At the same study (Ates, 2007), religion is effective on $45 \%$ investors' decision making but in this study only $28,7 \%$ of investors are effected by religion on their decision making. At this point, it can be said that cities socio-cultural structures are different from each other.

Canbas and Kandir (2007) and Ates (2007) found that in their studies, investors are affected from society than male investors. Also as, the level of education and transaction year in bourse increases, investors move away from herd psychology.

\section{Conclusion and Comments}

The study has some limitations:

It is impossible to generalise the results of the study to all Turkey investors. It is valid for only Kocaeli City, which located in East Marmara in Turkey.

Only a small number of female subjects reached, therefore, no significant results achieved on the basis of gender. Therefore, a comparison between female and male behaviour regarding financial markets did not carry out.

Though study's limitations, it can be done some inferences. Common tendencies of respondents can be summarised as follows:

The majority of investors in Kocaeli are men. One of three investors was aged between 25-44. Nearly half of the respondents worked in the private sector. The income of three of five investors' was $2000 \mathrm{TL}$. The average trading experience of investors in the bourse was eight years. An increase of experience in the bourse increased the average investment level in a month. Nearly half of investors traded a minimum monthly investment of 3000 TL.

When making decisions about investment, political instability was the most important factor for investors and the directions of intermediations were the least important factor for them. The constitution crisis that occurred in 2001 in Turkey is a possible example of such a conclusion. As a result, turmoil in the financial markets 
experienced, leading to a decrease in the rate of $\% 15$ in bourse, a jump in the repo interests rate of $\% 760$ and an exchange rate of $7600 \mathrm{TL}$ foreign exchange according to the Central Bank.

Low-earning investors who take little risk dominate to those who earn big while taking risks. Also, it has identified that investors' preferring $\% 100$ probability profit percentage increased depending on increases in the age of investors and decreases in the average monthly investment amount.

The study has concluded that investors who invest on average $3000 \mathrm{TL}$ and those whose trading period is over that of others prefer long-term investments to capturing profits from changes in the bourse.

In the study, it has emerged that investors who invest more than 10 years trust themselves and the information they have about financial markets more than other investors. Investors participating in the study specified that they prefer to wait to claim their losses. After abandoning stocks believed to gain in value, investors feel remorse.

Turkey is a developing country. As a result, its financial markets have relatively little depth. The current state has been supported by the data, taken for the study such as the small number of female investors relative to that of male investors a lack of transaction amounts, investors' having less technical information about financial markets, and being open to the effects of speculation.

Investors when making investments not only consider their minds, they also consider some environmental factors. The results of study supported that different factors affected investors' investment decision-making. The study is also important because it indicates efficient market hypothesis is not valid in some cases.

In the light of findings, some suggestions can be presented to further studies:

Complemantarity of information obtained through research depends on more sampling and different variables for analysis. So that, further studies can be enrich with new and different variables.

Implementation of further studies in stable economic conditions may cause to emerge different results. Therefore, it is important to implement further studies at the time of stable economic conditions to compare the results of studies.

For further studies why females made less investment in bourse comparison with males can be a new study area.

As a consequence, the results of study are important to lead further studies.

\section{References}

Akbulut Ramazan \& Kaderli Yusuf. (2009). Şanlıurfa Il Merkezindeki Borsa Yatirimcilarinin Profili ve Bu Yatirimcilarin Hisse Senetlerine Yatirim Yapma Sürecini Etkileyen Faktorlerin Analizi, Muhasebe ve Finansman Dergisi, 43, 212 - 226.

Assael Henry. (1984). Consumer Behavior and Marketing Action, Second Ed., Boston, Kent Publishing Com.

Ateş Alper. (2007). Finansal Yatirimlarin Davranissal Finans Acisindan Değerlendirilmesi Uzerine Bir Arastirma, Master Thesis, Selcuk Universitesi, Konya.

Barak Osman \& Demireli Erhan. (2006). IMKB'de Gözlemlenen Fiyat Anomalilerinin Davranışsal Finans Modelleri Kapsamında Değerlendirilmesi. 10. National Finance Symposium, Dokuz Eylül University, Selcuk-İzmir.

Barberis Nicholas, Shleifer Andrei \& Vishny Robert. (1998). A Model of Investor Sentiment. Journal of Financial Economics, 49, 307 - 343.

Bostanci Faruk. (2003). Davranısci Finans, Sermaye Piyasası Kurulu Denetleme Dairesi Yeterlik Etudu, Istanbul.

Bromiley Philip \& Wade Sharon James. (2003). Putting Rational Blinders Behind Us: Behavioural Understandings of Finance and Strategic Management. Longe Range Planning, 36, 37 - 48.

Canbas Serpil \& Kandir Serkan Yilmaz. (2007). Yatirimci Duyarliliginin IMKB Sektor Getirileri Uzerindeki Etkisi. Dokuz Eylul Universitesi Iktisadi ve Idari Bilimler Fakultesi Dergisi, 22, 219 - 248.

Daniel Kent, Hirshleifer David \& Subrahmanyam Avanidhar. (1998). Investor Psychology and Security Market Under and Overreactions. The Journal of Finance, LIII, 1839-1885.

de Bondt Werner. (1998). Behavioral Economics A Portrait of the Individual Investor. European Economic Review, 42, $831-844$.

Dom Serpil. (2003). Yatırımcı Psikolojisi. Istanbul, Degisim Yayinlari.

Estrada, Javier. (2010). Law and Behavioral Economics, 2001; 5: 1 - 17, [Online] Available: http://web.iese.edu.jestrada/PDF/research/ Others/L\&BE. Pdf (29.01.2010)

Fuller Russell. (1998). Behavioral Finance and the Sources of Alpha. Journal of Pension Plan Investing, $2,1-$ 24.

Macgregor Donald. (2002). Imagery and Financial Judgment. The Journal of Psychology and Financial Markets, $3,15-22$. 
Olsen Robert. (1998). Behavioral Finance and Its Implications for Stock-Price Volatility. Financial Analysts Journal, 54, $10-18$.

Ritter Jay. (2003). Behavioral Finance. Pasific-Basin Finance Journal, 11, 429 - 437.

Shiller Robert. (1998). Human Behavior and the Efficiency of the Financial System. NBER Working Paper 6375. Statman Meir. (2002). Lottery Players/Stock Traders. Financial Analysts Journal, 58, 14 - 21.

Zopounidis Constantin \& Doumpos Michael. (2002). Multi-criteria Decision Aid in Financial Decision Making: Methodologies and Literature Review. Journal of Multi Criteria Decision Analysis, 11, 167 - 186.

Table 1. The assumptions of Behavioural Finance and EMH

\begin{tabular}{|ll|ll|}
\hline EMH (Estrada, 2001) & \multicolumn{2}{|l|}{ Behavioural Finance (Estrada, 2001) } \\
\hline 1. & There are not any transaction costs. & 1. & Investors act more efficiently to maximise their portfolios. \\
2. & Markets are not segmented. & 2. & Investors behave according to their interest. \\
3. & Entering to markets is easy or limited. & & \\
\hline
\end{tabular}

Table 2. Investors Profile

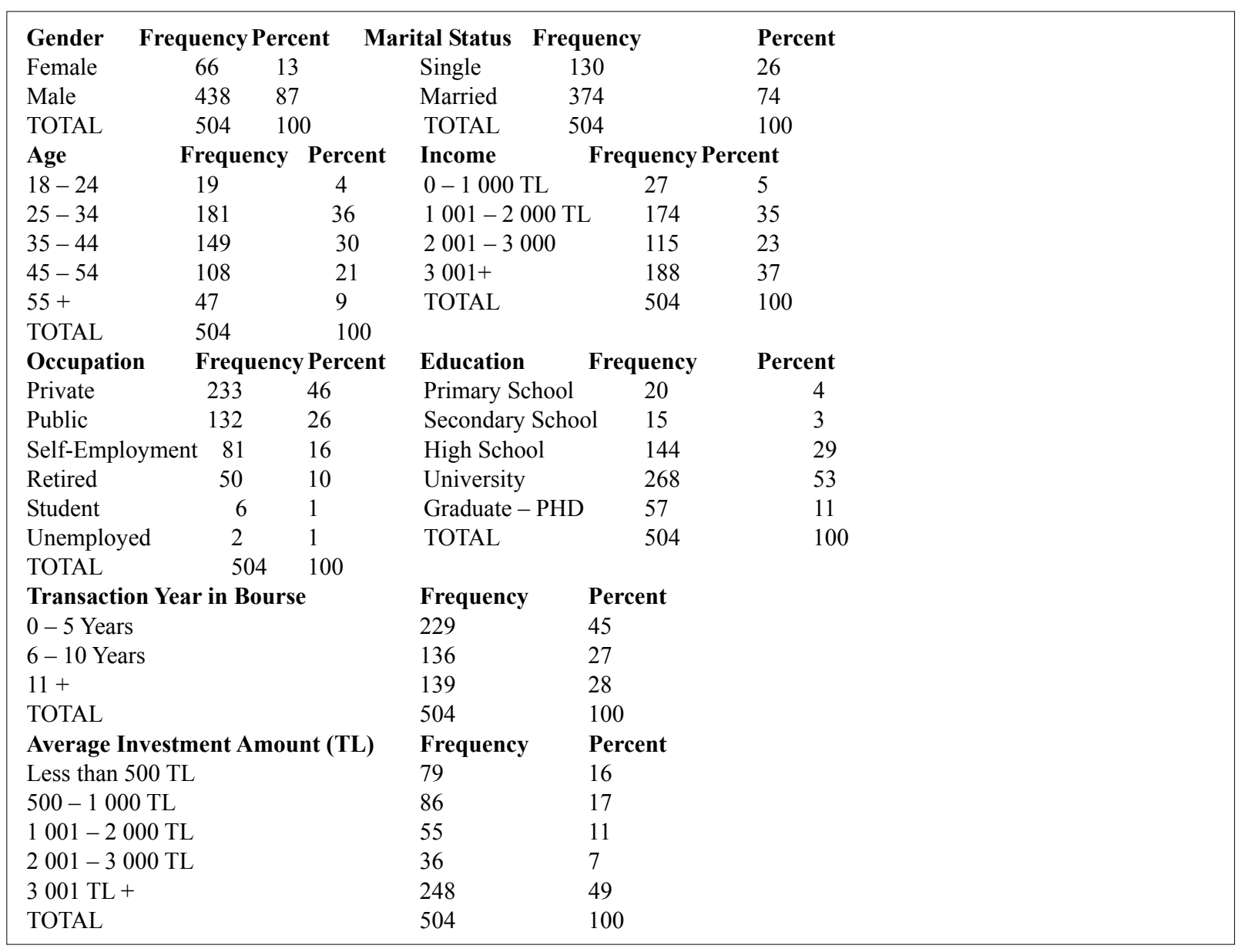


Table 3. Importance Rate of Factors that Affect Investors' Decision-Making Process in the Bourse

\begin{tabular}{|c|c|c|c|c|c|c|c|c|c|c|c|c|}
\hline \multirow[b]{2}{*}{ Factors } & \multicolumn{4}{|c|}{$\leftarrow$ Never Important } & \multicolumn{2}{|c|}{ Neutral } & \multicolumn{4}{|c|}{ Very Important $\rightarrow$} & \multirow[b]{2}{*}{$\mathbf{N}$} & \multirow[b]{2}{*}{ Average } \\
\hline & One & Two & Three & Four & Five & Six & Seven & Eight & Nine & Ten & & \\
\hline $\begin{array}{l}\text { Risk Level of Investment } \\
\text { Instrument }\end{array}$ & 4,2 & 1,6 & 2,8 & 1,8 & 14,7 & 10,5 & 13,3 & 15,5 & 7,7 & 28,0 & 504 & 7,26 \\
\hline Inflation Ratio & 13,3 & 7,3 & 6,7 & 6,7 & 15,1 & 9,3 & 12,1 & 10,7 & 5,8 & 12,9 & 504 & $\mathbf{5 , 5 8}$ \\
\hline Volatility of Exchange Rate & 6,9 & 3,6 & 5,2 & 5,4 & 13,9 & 8,5 & 13,9 & 14,1 & 9,5 & 19,0 & 504 & 6,58 \\
\hline Market Interest Rate & 7,1 & 4,6 & 6,0 & 3,6 & 12,7 & 9,3 & 14,3 & 15,9 & 6,3 & 20,2 & 504 & 6,54 \\
\hline Political Instability & 4,2 & 1,4 & 3,0 & 1,8 & 6,0 & 4,6 & 6,2 & 14,9 & 13,5 & 44,6 & 504 & 8,10 \\
\hline Past Performance of Stocks & 2,6 & 1,2 & 1,8 & 4,0 & 13,3 & 9,1 & 15,5 & 18,7 & 10,7 & 23,2 & 504 & 7,34 \\
\hline $\begin{array}{l}\text { Improvements in International } \\
\text { Financial Markets }\end{array}$ & 2,2 & 2,2 & 2,8 & 4,4 & 9,7 & 9,9 & 16,7 & 19,6 & 9,3 & 23,2 & 504 & 7,30 \\
\hline Directions of Intermediations & 13,9 & 11,5 & 9,1 & 7,3 & 16,5 & 9,7 & 9,9 & 11,5 & 3,4 & 7,1 & 504 & 4,98 \\
\hline News about Stocks in Media & 7,5 & 4,4 & 7,7 & 3,4 & 15,1 & 8,9 & 15,3 & 17,1 & 6,5 & 14,1 & 504 & 6,25 \\
\hline Personal Perceptions & 3,6 & 2,4 & 3,4 & 5,2 & 15,3 & 10,9 & 15,3 & 15,1 & 8,5 & 20,4 & 504 & 6,90 \\
\hline TOTAL & 6,5 & 4,0 & 4,8 & 4,3 & 13,2 & 9,1 & 13,2 & 15,3 & 8,1 & 21,3 & 504 & 6,68 \\
\hline
\end{tabular}

Table 4. Analysis Results of the item "The Item of the Bourse is a Gamble"

\begin{tabular}{|l|lllll|}
\hline & & $\mathrm{N}$ & Average & $\mathrm{F}$ & Sig. \\
\hline Transaction & $0-5$ Years & 229 & 2,79 & & \\
$\begin{array}{l}\text { Year } \\
\text { in Bourse }\end{array}$ & 6-10 Years & 136 & 2,86 & 5,677 & 0,004 \\
& 11 Year + & 139 & 2,39 & & \\
TOTAL & & $\mathbf{5 0 4}$ & & & \\
\hline \multirow{5}{*}{ Education } & Primary School & 35 & 2,54 & & \\
& High School & 144 & 2,71 & 0,403 & 0,751 \\
& University & 268 & 2,74 & & \\
TOTAL & Graduate - PHD & 57 & 2,58 & & \\
\hline & Private Sector & 233 & 2,68 & & \\
Occupation & Public Sector & 132 & 2,89 & & \\
& Self - Employment & 81 & 2,65 & 2,604 & 0,035 \\
& Retired & 50 & 2,24 & & \\
& Other & 8 & 3,12 & & \\
& (unemployment, & & & & \\
TOTAL & student etc.) & & & & \\
\hline
\end{tabular}

Table 5. Analysis Results of the Item "When Deposit Rates Decrease, the Bourse is the only Investment Area"

\begin{tabular}{|c|c|c|c|c|c|}
\hline & & $\mathrm{N}$ & Average & $\mathrm{F}$ & Sig. \\
\hline \multirow{5}{*}{ Age } & $18-24$ Ages & 19 & 3,47 & \multirow{6}{*}{3,483} & \multirow{6}{*}{0,008} \\
\hline & $25-34$ Ages & 181 & 2,77 & & \\
\hline & 35 - 44 Ages & 149 & 2,61 & & \\
\hline & $45-54$ Ages & 108 & 2,65 & & \\
\hline & $55 \mathrm{Age}+$ & 47 & 3,06 & & \\
\hline TOTAL & & 504 & & & \\
\hline \multirow[t]{3}{*}{ Marital Status } & Single & 130 & 2,97 & \multirow[t]{3}{*}{6,233} & \multirow[t]{3}{*}{0,013} \\
\hline & Married & 374 & 2,67 & & \\
\hline & & 504 & & & \\
\hline
\end{tabular}


Table 6. Analysis Results of the Item "Over Periods of Price Increases or Decreases, the Bourse is a Convincing Investment Instrument for Investors Who Want to Invest in the Long Term"

\begin{tabular}{|c|c|c|c|c|c|}
\hline & & $\mathrm{N}$ & Average & $\mathrm{F}$ & Sig. \\
\hline \multirow{6}{*}{ Average Investment Amount } & Less than $500 \mathrm{TL}$ & 79 & 3,44 & \multirow{6}{*}{2,880} & \multirow{6}{*}{0,022} \\
\hline & $500-1000 \mathrm{TL}$ & 86 & 3,28 & & \\
\hline & $1001-2000 \mathrm{TL}$ & 55 & 3,33 & & \\
\hline & $2001-3000 \mathrm{TL}$ & 36 & 3,69 & & \\
\hline & $3001 \mathrm{TL}+$ & 248 & 3,65 & & \\
\hline & & 504 & & & \\
\hline \multirow{4}{*}{$\begin{array}{l}\text { Transaction Year } \\
\text { in Bourse }\end{array}$} & $0-5$ Years & 229 & 3,40 & \multirow{4}{*}{3,232} & \multirow{4}{*}{0,04} \\
\hline & $6-10$ Years & 136 & 3,58 & & \\
\hline & 11 Year + & 139 & 3,68 & & \\
\hline & & 504 & & & \\
\hline
\end{tabular}

Table 7. Analysis Results of the Item "I Think I have enough Knowledge about the Bourse"

\begin{tabular}{|c|c|c|c|c|c|}
\hline & & $\mathrm{N}$ & Average & $\mathrm{F}$ & Sig. \\
\hline $\begin{array}{l}\text { Transaction Year } \\
\text { in Bourse } \\
\text { TOTAL }\end{array}$ & $\begin{array}{l}0-5 \text { Year } \\
6-10 \text { Year } \\
11 \text { Year }\end{array}$ & $\begin{array}{l}229 \\
136 \\
139 \\
\mathbf{5 0 4}\end{array}$ & $\begin{array}{l}2,97 \\
3,32 \\
3,45\end{array}$ & 9,921 & 0,000 \\
\hline
\end{tabular}

Table 8. Analysis Results of The Item "Investors Who Ensured the Viability of an Investment Portfolio by Purchasing Stocks on Hand are Always More Profitable than Investors That Wait for the Long Term"

\begin{tabular}{|c|c|c|c|c|c|}
\hline & & $\mathrm{N}$ & Average & $\mathrm{F}$ & Sig. \\
\hline Age & $18-24$ Ages & 19 & 3,69 & 2,510 & 0,041 \\
\hline & 25 - 34 Ages & 181 & 3,11 & & \\
\hline & 35 - 44 Ages & 149 & 3,08 & & \\
\hline & $45-54$ Ages & 108 & 2,82 & & \\
\hline & $55 \mathrm{Age}+$ & 47 & 3,17 & & \\
\hline Marital & Single & 130 & 3,26 & 4,568 & 0,033 \\
\hline Status & Married & 374 & 3,00 & & \\
\hline TOTAL & & 504 & & & \\
\hline Transaction Year & $0-5$ Years & 229 & 3,24 & & \\
\hline in Bourse & $6-10$ Years & 136 & 3,10 & 6,865 & 0,001 \\
\hline & 11 Year + & 139 & 2,76 & & \\
\hline TOTAL & & 504 & & & \\
\hline
\end{tabular}

Table 9. Analysis Results of the Item "I Think that in the Coming Year, Investments Provide Higher Returns than the Average Market"

\begin{tabular}{|l|lllll|}
\hline & & $\mathrm{N}$ & Average & $\mathrm{F}$ & Sig. \\
\hline Marital & Single & 130 & 3,52 & 5,981 & 0,015 \\
Status & Married & 374 & 3,24 & & \\
TOPLAM & & $\mathbf{5 0 4}$ & & & \\
\hline Average & Less than 500 TL & 79 & 2,96 & & \\
Investment & $500-1000 \mathrm{TL}$ & 86 & 3,21 & & \\
Amount & $1001-2000 \mathrm{TL}$ & 55 & 3,31 & 3,385 & 0,010 \\
in one & $2001-3000 \mathrm{TL}$ & 36 & 3,56 & & \\
month & $3001+$ & 248 & 3,43 & & \\
TOPLAM & & $\mathbf{5 0 4}$ & & & \\
\hline
\end{tabular}

Table 10. Analysis Results of the Item "If Stocks I Purchased Lose, I Prefer to Wait to Claim my Losses"

\begin{tabular}{|c|c|c|c|c|c|}
\hline & & $\mathrm{N}$ & Average & $\mathrm{F}$ & Sig. \\
\hline \multirow{4}{*}{ Income } & $0-1000 \mathrm{TL}$ & 27 & 2,93 & & \\
\hline & $1001-2000 \mathrm{TL}$ & 174 & 3,22 & 3,714 & 0,012 \\
\hline & $2001-3000 \mathrm{TL}$ & 115 & 2,99 & & \\
\hline & $3001+$ & 188 & 2,81 & & \\
\hline TOPLAM & & 504 & & & \\
\hline
\end{tabular}


Table 11. Analysis Results of The Item "My Religious Beliefs have an Important Effect on my Investment Decisions"

\begin{tabular}{|l|lllll|}
\hline & & $\mathrm{N}$ & Average & $\mathrm{F}$ & $\mathrm{Sig}$. \\
\hline Gender & Female & 66 & 1,98 & 10,149 & 0,002 \\
& Male & 438 & 2,52 & & \\
TOTAL & & $\mathbf{5 0 4}$ & & & \\
& Primary School & 35 & 3,20 & & \\
Education & High School & 144 & 2,65 & 7,629 & 0,000 \\
& University & 268 & 2,28 & & \\
& Graduate - PHD & 57 & 2,25 & & \\
TOTAL & & $\mathbf{5 0 4}$ & & & \\
\hline
\end{tabular}

Table 12. Analysis Results of The Item "Investment Instruments that Investors choose more always provide higher returns"

\begin{tabular}{|l|lllll|}
\hline & & $\mathrm{N}$ & Average & $\mathrm{F}$ & Sig. \\
\hline Gender & Female & 66 & 3,08 & 4,115 & 0,043 \\
TOTAL & Male & 438 & 2,77 & & \\
Transaction Year & & $\mathbf{5 0 4}$ & & & \\
in Bourse & $0-5$ Years & 229 & 2,92 & & \\
Transaction Year & $6-10$ Years & 136 & 2,83 & 3,151 & 0,044 \\
TOTAL & $11+$ & 139 & 2,62 & & \\
& & $\mathbf{5 0 4}$ & & & \\
Education & Primary School & 35 & 3,29 & & \\
& High School & 144 & 2,94 & 4,651 & 0,003 \\
& University & 268 & 2,76 & & \\
TOTAL & Graduate - PHD & 57 & 2,47 & & \\
\hline
\end{tabular}

Table 13. Frequencies of Preferred Investment Profit Chosen by Investors

\begin{tabular}{|l|lll|}
\hline & & $\mathrm{N}$ & $\%$ \\
\hline Preferred & $\% 100$ probability 3 000 TL profit & 283 & 56 \\
Profit & $\% 80$ probability 4 000 TL profit & 221 & 44 \\
TOTAL & & $\mathbf{5 0 4}$ & $\mathbf{1 0 0}$ \\
\hline
\end{tabular}

Table 14. Relationship between Preferred Profit and Average Investment Amount in one Month

\begin{tabular}{|l|lcccccc|}
\hline & & $\begin{array}{c}\% \\
000 \mathrm{TL} \text { profit }\end{array}$ & $\begin{array}{c}\text { \% } 80 \text { probability } \\
000 \text { TL profit }\end{array}$ & $\mathrm{N}$ & $\mathrm{X}^{2}$ & Sig. \\
\hline Average & Less than $500 \mathrm{TL}$ & 55 & 24 & 79 & 11,293 & 0,023 \\
Investment & $500-1000 \mathrm{TL}$ & 53 & 33 & 86 & & \\
Amount & $1001-2000 \mathrm{TL}$ & 32 & 23 & 55 & & \\
in one & $2001-3000 \mathrm{TL}$ & 20 & 16 & 36 & & \\
month & $3001+$ & 123 & 125 & 248 & & \\
TOTAL & & $\mathbf{2 8 3}$ & $\mathbf{2 2 1}$ & $\mathbf{5 0 4}$ & \\
\hline
\end{tabular}




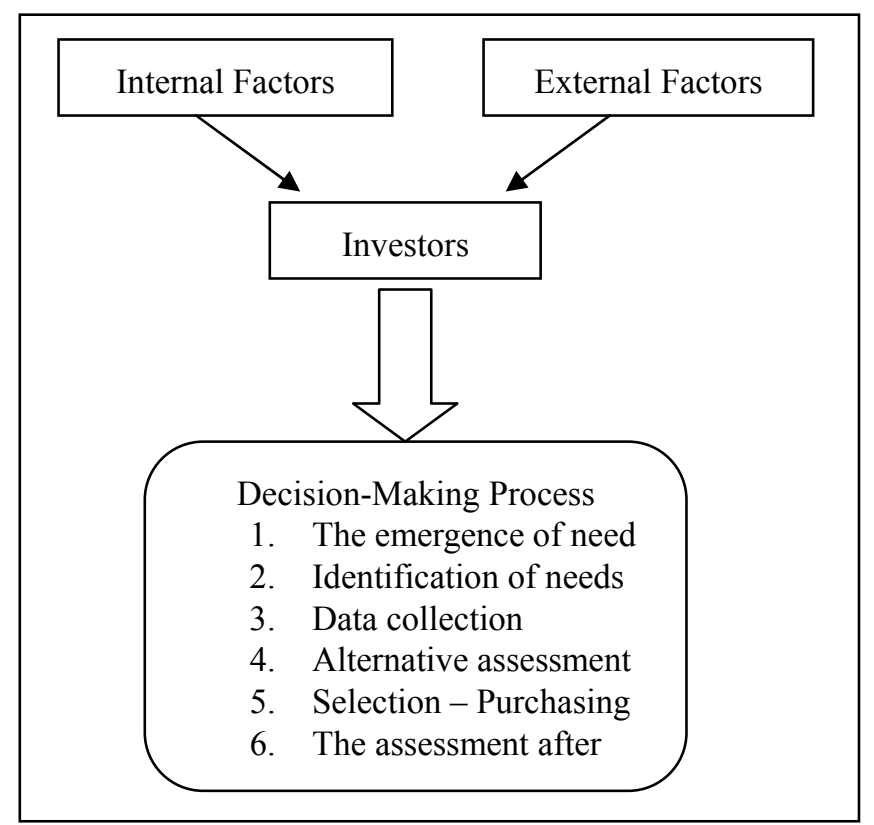

Figure 1. Decision-Making Process 